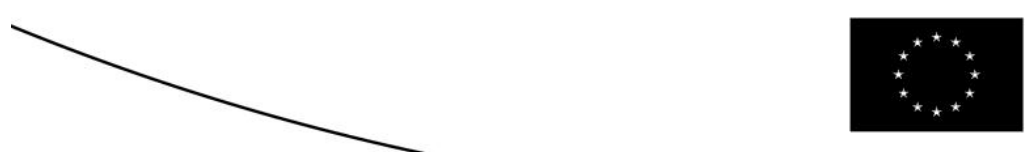

COUNCIL OF

Brussels, 15 January 2002 (21.01)

THE EUROPEAN UNION

(OR. fr)

$5327 / 02$

LIMITE

COPEN 4

CATS 1

NOTE

from : $\quad$ Spanish Presidency

to : $\quad$ Article 36 Committee

No. prev. doc. : 14867/1/01 COPEN 79 CATS 50 REV 1 ADD 2

Subject : $\quad$ Proposal for a Council Framework Decision on the European arrest warrant and the surrender procedures between Member States

- ANNEX

\title{
ANNEX
}

\section{EUROPEAN ARREST WARRANT}

I hereby certify that this warrant corresponds to the authentic documents on which the warrant is based and request that the person mentioned below be arrested and surrendered to the judicial authority mentioned below: 
(a) Information regarding the identity of the requested person:

Name:

Forename(s):

Maiden name, where applicable:

Aliases, where applicable:

Sex:

Nationality:

Date of birth:

Place of birth:

Residence (or last known residence):

Language(s) which the requested person understands (if known):

Distinctive marks/description of the requested person:

Photo and fingerprints of the requested person (if available):

(b) The judicial authority which issued the request and to which the person is to be surrendered: Jurisdiction:

Name of the issuing magistrate:

Post held (title/grade):

File reference:

Address:

Tel. No: 
Fax No:

Where a central authority has been made responsible for the transmission and administrative reception of European arrest warrants

Name of the central authority:

Contact person, if applicable (title/grade and name):

Address:

Tel. No:

Fax No:

E-mail:

(c) Enforceable judgement, arrest warrant or other judicial decision having the same force:

Type:

Date:

Reference:

Date of enforceability: 
(d) Indicate whether one of the following offences is involved and if they are punishable in the issuing Member State by a custodial sentence of a maximum of at least 3 years and as they are defined by the law of the issuing Member State (Mark the appropriate box):

participation in a criminal organisation;

terrorism;

trafficking in human beings;

sexual exploitation of children and child pornography;

illicit trafficking in narcotic drugs and psychotropic substances;

illicit trafficking in weapons, munitions and explosives;

0 corruption;

0 fraud, including that affecting the financial interests of the European Communities within the meaning of the Convention of 26 July 1995 on the protection of European Communities' financial interests;

0 laundering of the proceeds of crime;

0 counterfeiting of euro;

$0 \quad$ computer-related crime;

0 environmental crime, including illicit trafficking in endangered animal species and in endangered plant species and varieties;

0 facilitation of unauthorised entry and residence;

0 murder, grievous bodily injury;

$0 \quad$ illicit trade in human organs and tissue;

$0 \quad$ kidnapping, illegal restraint and hostage-taking;

0 racism and xenophobia;

0 organised or armed robbery;

$0 \quad$ illicit trafficking in cultural goods, including antiques and works of art;

0 swindling;

$0 \quad$ racketeering and extortion; 


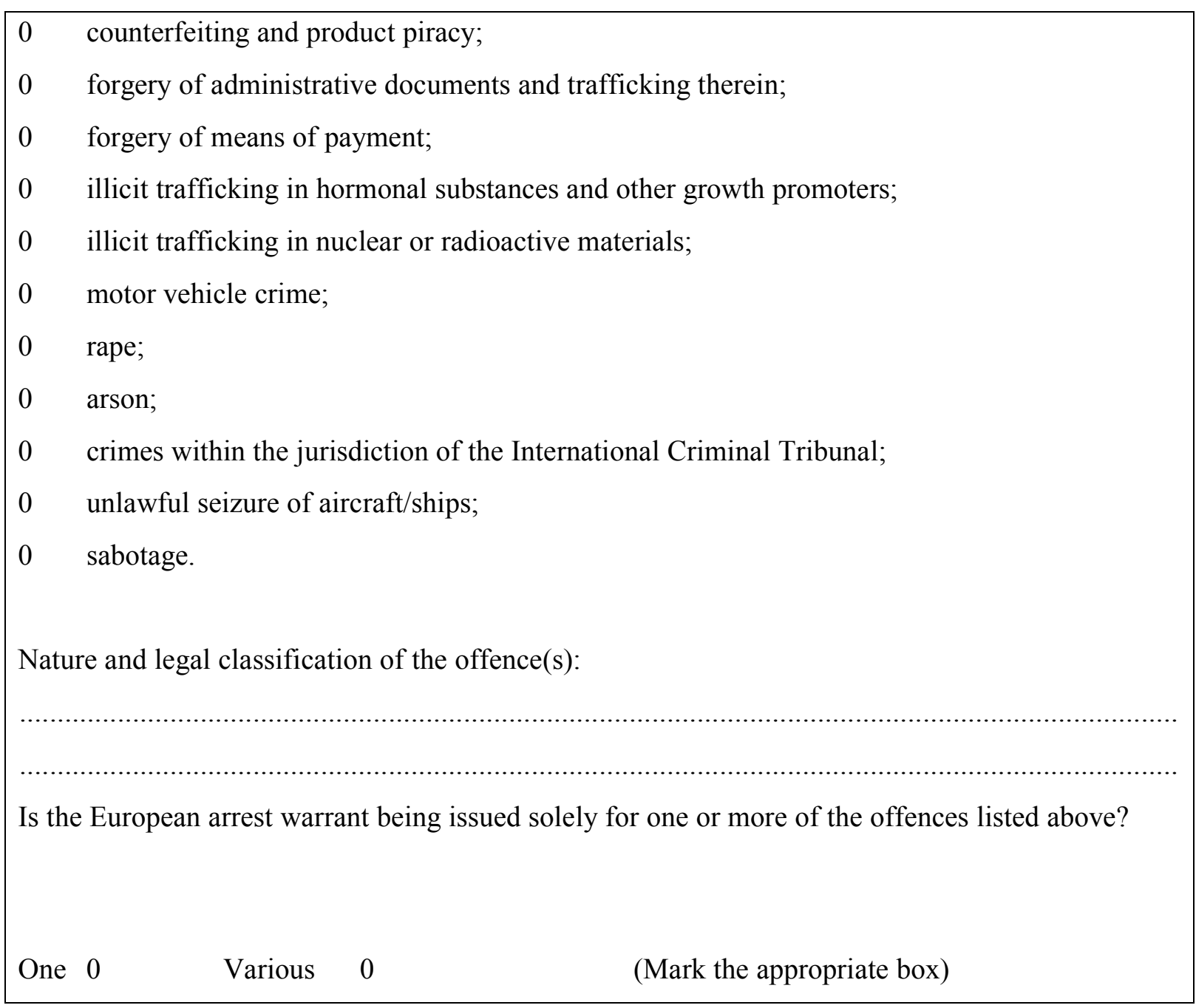

(e) Description of the circumstances in which the offence was committed including the:

- $\quad$ time of the offence;

- date on which judicial proceedings were initiated;

- date of other circumstances which may interrupt the period of limitation;

- $\quad$ place where the offence was committed;

- degree of participation;

- other circumstances. 
(f) If there is an enforceable criminal judgement, what is the custodial sentence or detention order?

Remaining sentence to be served:

If there is an arrest warrant or other judicial decision having the same force, what is the scale of the prescribed penalty and the maximum sentence?

(g) Other consequences of the offence(s) [...]:

(h) Has the European arrest warrant been issued for the purposes of executing a sentence or a detention order imposed by a decision rendered in absentia?

$\begin{array}{llll}\text { Yes } & 0 & \text { No } & 0\end{array}$ (Mark the appropriate box)

If the answer is "yes", has the person concerned been summoned in person or otherwise informed of the date and place of the hearing which led to the decision rendered in absentia?

$\begin{array}{lllll}\text { Yes } & 0 & \text { No } & 0 & \text { (Mark the appropriate box) }\end{array}$

Judicial guarantees to be provided by the judicial authority of the issuing State if the delivery is granted: 
(i) Judicial guarantees to be provided by the judicial authority of the issuing State if the delivery is granted in the case of a sentence of life imprisonment:

(j) The issuing judicial authority also requests the confiscation and handing over of property which may be required as evidence:

Yes 0 No 0 (Mark the appropriate box)

The issuing judicial authority also requests the seizure and handing over of property acquired by the requested person as a result of the offence:

Yes 0 No 0 (Mark the appropriate box)

Description of the property if known:

Signature of the competent magistrate:

Title:

Post held:

Jurisdiction: 